\title{
MANAGEMENT OF INSECT PESTS OF VIGNA RADIATA (L.) WILCZEK
}

\author{
K. SINGH ${ }^{1}-$ U.S. SHARMA ${ }^{1}-$ R. SWAMINATHAN ${ }^{1 *}-$ P.K. DASHORA ${ }^{2}$ \\ ${ }^{1}$ Assoc. Prof. Department of Entomology, Rajasthan College of Agriculture, Guru Gobind Singh \\ Marg, Udaipur - 313 001, India \\ ${ }^{2}$ Assoc. Prof. Department of Statistics, Rajasthan College of Agriculture, MPUAT, Udaipur- \\ 313 001, Rajasthan, India \\ *Corresponding author \\ e-mail: udaiswamirussia@yahoo.co.uk,tumbi_russia@yahoo.com \\ (Received $16^{\text {th }}$ April 2008 ; accepted $6^{\text {th }}$ July 2009)
}

\begin{abstract}
Investigation on the evaluation of certain management schedules against major insect pests of Vigna radiata (L.) Wilczek, was carried out for two crop seasons (July to October 2001 and 2002) at the Agronomy Farm and the Department of Agricultural Zoology and Entomology of Rajasthan College of Agriculture, Maharana Pratap University of Agriculture \& Technology, Udaipur, India. The efficacy of Azadirachta indica A. Juss oil and malathion, as first application against aphids, jassids and whiteflies was significantly lower under sole crop of $V$. radiatal than when it was inter-cropped with maize during both years (2001 and 2002). Among the different treatment schedules as third application, endosulfan was most effective against the pod borers (Maruca testulalis Geyer and Lampides boeticus L.) in both sole crop and the intercrop. During the two-year study (2001 and 2002), the maximum yield of maize and green gram in the inter-cropped pattern and that as sole crop of green gram, as well as the maximum rupee equivalent yield value was recorded for the management schedule comprising release of Chrysoperla carnea 25 DAS, spray of A. indica oil 40 DAS and endosulfan 55 DAS. The lowest yield of $V$. radiata was recorded under the management schedule comprising three release of Chrysoperla carnea Stephen at 25, 40 and 55 DAS irrespective of the cropping pattern.
\end{abstract}

Keywords: Management, insect pests, Vigna radiata, Lampides boeticus, Maruca testulalis

\section{Introduction}

Pulses occupy a unique position in the agricultural economy of India being the major source of proteins in Indian dietary. Moreover, their role in improving the fertility of the soil, by microbial fixation of atmospheric nitrogen, further enhances their importance and utility. Traditionally, the farmers grow pulses as companion crops on marginal and unirrigated lands. The area covered by pulses in the country is 14.35 per cent of the total cropped area. Vigna radiata (L.) Wilczek is a native of India and Central Asia and has been grown in these regions since prehistoric times (8). It is an important source of easily digestible high quality protein for vegetarians and sick persons and contains 24 per cent protein, 0.326 per cent phosphorus, 0.0073 per cent iron, 0.00039 per cent carotene, 0.0021 per cent of niacin and energy $334 \mathrm{cal} / 100 \mathrm{~g}$ of green gram (4). A number of factors are responsible for its low yield, however, losses caused by insect pests are one of the major factors, therefore, proper and effective pest management methods should be adopted to minimize the losses caused by them. Hence, different management schedules to curb insect pests of $V$. radiata as sole crop and when intercropped with maize were evaluated. 


\section{Materials and Methods}

\section{Crop cultivation}

To evaluate the effect of intercropping green gram with maize as a component in the management of insect pests, sole crop of green gram was sown in plots of size $12 \mathrm{~m}^{2}$ $(4 \mathrm{~m} \times 3 \mathrm{~m})$ maintaining the row-to-row spacing at $30 \mathrm{~cm}$ and plant-to-plant distance at 10 $\mathrm{cm}$. In the intercropped system, green gram and maize (1:1 ratio) were sown in plots of $12 \mathrm{~m}^{2}$ as alternative rows at a distance of $30 \mathrm{~cm}$ apart. The experiment was laid out as a factorial RBD. Sole green gram formed one block and the intercrop formed another block. There were 6 treatments in each block accruing to 12 treatments in all that were replicated thrice.

Management of the major insect pests viz., aphids, jassids, white flies and the pod borer complex (Lampides boeticus Linnaeus and Maruca testulalis Geyar) was manifested using a combination of the botanical ( $A$. indica oil), the bio-agent (Chrysoperla carnea Stephen) and insecticide (malation and endosulfan treatments. The efficacy of various treatment schedules on these insect pests of green gram, when grown as a sole crop, or when intercropped with maize was studied by observing the reduction in population of the sucking pests and the per cent pod infestation due to the pod borer complex after the first and third application only. The second application comprised release of $C$. carnea at 40 DAS and one spray of $A$. indica oil $(0.2 \%)$ at 40 DAS and was evaluated as the overall effect on yield and rupee equivalent parameters.

\section{Treatment schedules}

$\mathrm{T}_{1}=$ Spraying of malathion $(0.05 \%)$ at 25 days after sowing and endosulfan $(0.07$ per cent) at 55 days after sowing.

$\mathrm{T}_{2}=$ Three releases of Chrysoperla carnea Stephen @ 25000 neonate larvae per hectare 25 DAS, at 40 DAS and at 55 DAS.

$\mathrm{T}_{3}=$ Three sprays of Azadirachta indica A. Juss oil (0.2\%) at 25 DAS, at 40 DAS and at 55 DAS.

$\mathrm{T}_{4}=$ Release of $C$. carnea @ 25000 neonate larvae per hectare at 25 DAS, spraying of A. indica oil $(0.2 \%)$ at 40 DAS and malathion $(0.05 \%)$ at 55 DAS.

$\mathrm{T}_{5}=$ Release of $C$. carnea @ 25000 neonate larvae per hectare at 25 DAS, spraying of A. indica oil $(0.2 \%)$ at 40 DAS and endosulfan $(0.07 \%)$ at 55 DAS.

$\mathrm{T}_{6}=$ Control

\section{Observations}

The population counts were made one day before the treatment application (pre treatment population), and 1, 3, 5 and 7 days after treatment (post treatment population) on five randomly selected plants for the sucking pests aphids, jassids and white flies. The reduction in population observed after the treatments were corrected applying the correction factor as given by Henderson and Tilton (1955). Likewise, for percent damage to pods due to the pod borer/s, ten plants were randomly selected and observations on percent damage to pods were made on these plants, 1, 3, 5 and 7 days after the treatment application. 


\section{Estimation of population reduction}

$$
\begin{aligned}
& \text { Reduction in population }(\%)=100 \times\left\{1-\frac{\mathrm{T}_{\mathrm{a}} \times \mathrm{C}_{\mathrm{b}}}{\mathrm{T}_{\mathrm{b}} \times \mathrm{C}_{\mathrm{a}}}\right\} \\
& \text { Where, } \\
& \qquad \mathrm{T}_{\mathrm{a}}=\text { Number of insects after treatments } \\
& \mathrm{T}_{\mathrm{b}}=\text { Number of insects before treatments } \\
& \mathrm{C}_{\mathrm{a}}=\text { Number of insects in untreated check after treatments } \\
& \mathrm{C}_{\mathrm{b}}=\text { Number of insects in untreated check before treatments }
\end{aligned}
$$

\section{Statistical analyses}

Statistical analyses were done only for comparing efficacy of insecticides and the botanical pesticide (A. india oil) at first and third application. The release of the bioagent, $C$. carnea was not compared with any of the other treatments for percent population reduction. However, the bio-agent release was compared with respect to percent pod infestation due to the pod borer complex at third application (i.e. 55 DAS). Besides, the overall effect of all the treatments after three applications at 25, 40 and 55 days after sowing was also evaluated after computing the rupee equivalent value for the yield obtained under each schedule.

\section{Results and Discussion}

The major insect pests recorded were aphids (Aphis craccivora Koch.), jassids (Empoasca kerri Pruthi and Empoasca sp.), whiteflies (Bemisia tabaci Genn) and the pod borer complex (Maruca testulalis Geyar and Lampides boeticus Linn).

\section{Efficacy of management schedules on population reduction of sucking pests}

\section{Aphids}

After the first application (25 DAS), the aphid population was significantly reduced under sole green gram 1, 3, 5 and 7 days after treatment rather than when inter-cropped with maize during both years (2001 and 2002). From the Table 1., this shows the relative population reduction of insect pests of Vigna radiata (L.) Wilckzek after pesticide application at $25 \mathrm{DAS}$, it can be inferred that the maximum reduction in the population of aphids occurred 5 days after treatment in the sole crop $(70.36 \%$ during 2001), while during 2002 malathion was more effective in the intercrop (52.49\%) and A. indica in sole crop (59.04\%). Malathion was as effective as A. indica oil 1, 3, 5 and 7 days after treatment irrespective of whether green gram was sown sole or inter-cropped with maize during 2001; whereas, during 2002 the efficacy of malathion was relatively better when green gram was inter-cropped with maize (Table 1.). Comparing the third application of the treatment schedules (55 DAS), it was observed that endosulfan was most effective in both sole green gram and the inter-crop, maize with green gram during both the years (2001 and 2002). A. indica oil treatment against aphids had an intermediate efficacy, whereas, malathion was least effective during both seasons [Table 2., showing relative population reduction of insect pests of Vigna radiata (L.) Wilckzek, after pesticide application at 55 DAS]. 
Table 1. Relative population reduction of insect pests of Vigna radiata (L.) Wilczek after pesticide application at 25 DAS

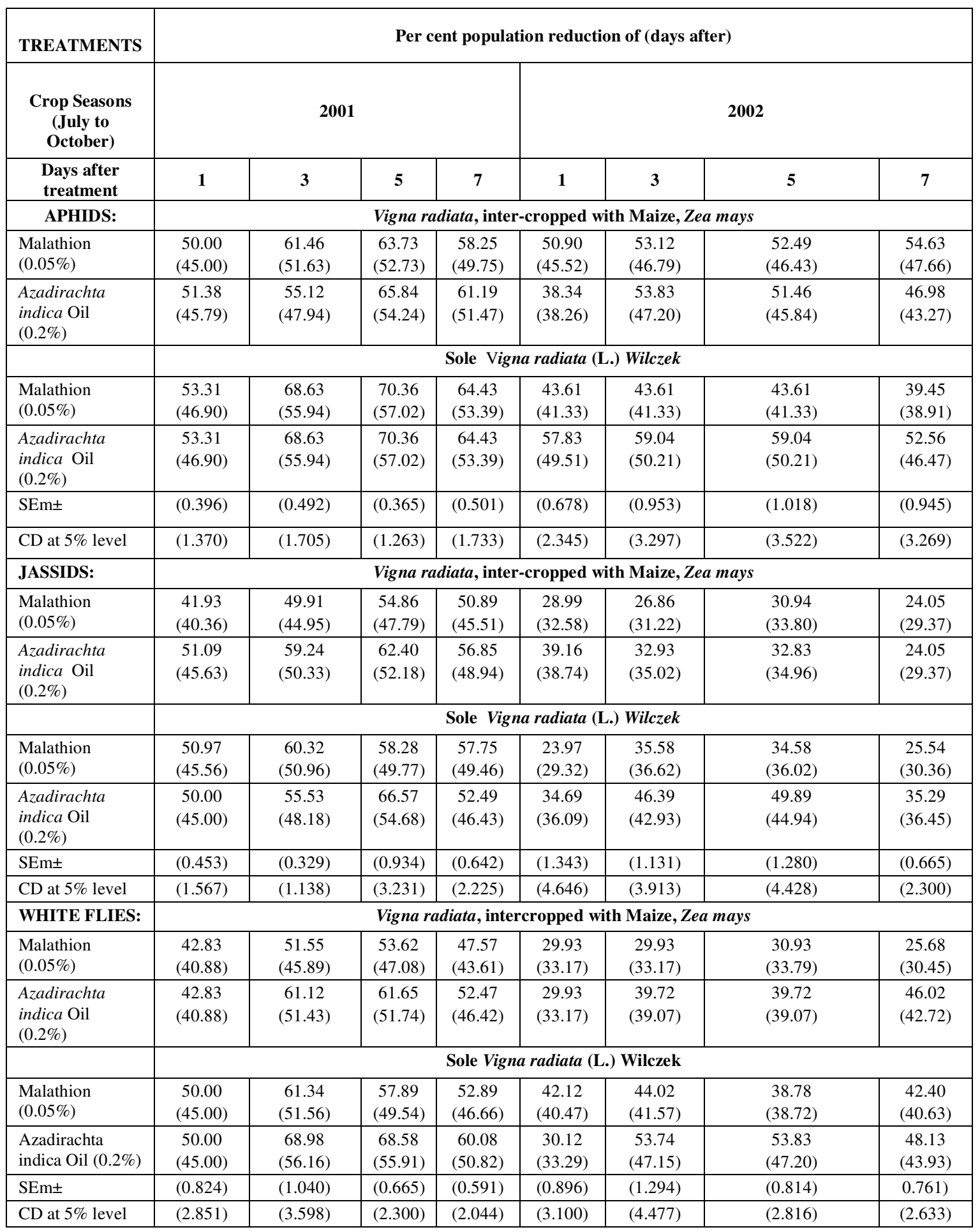

1. DAS $=$ Days after sowing.

2. Figures in parentheses are arc sine values of per cent reduction. 
Table 2. Relative population reduction of inset pests of Vigna radiata (L.) Wilczek after pesticide application at 55 DAS

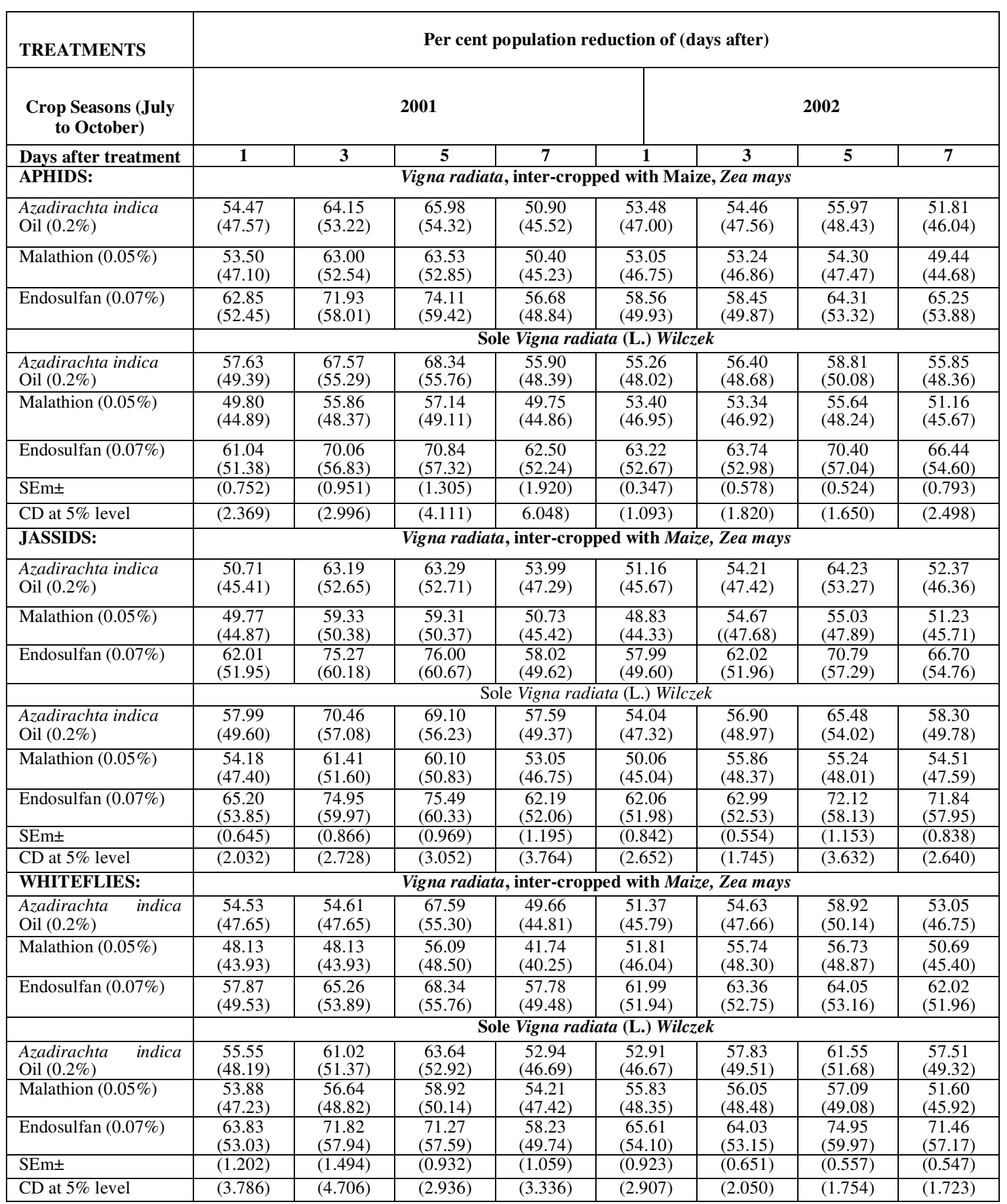

DAS = Days after sowing. Figures in parentheses are arc sine values of per cent reduction.

\section{Jassids}

Following the first application (25 DAS) malathion and endosulfan were significantly more effective in the sole crop 1, 3 and 7 days after application during 2001. However, the efficacy of $A$. indica oil was more pronounced in the inter-crop, while that of malathion was so in sole green gram. In the subsequent year (2002), $A$. 
indica oil was superior in the inter-crop 1 day after application, while its efficacy was superior in the management of jassids in sole green gram 3 and 5 days after treatment. Malathion happened to be less effective than A. indica oil against jassids in green gram inter-cropped with maize (Table 1). In the subsequent application (55 DAS) endosulfan was more superior to A. indica oil and malathion in both sole green gram and green gram inter-cropped with maize during 2001, but in the subsequent year (2002) endosulfan happened to be significantly better in the sole crop. During both seasons $A$. indica oil had an intermediate efficacy irrespective of the cropping pattern. Malathion was least effective during the two-year study under sole as well as the inter-crop (Table 2.).

\section{Whiteflies}

At first application (25 DAS), malathion and A. indica oil efficacy against whiteflies was significantly more pronounced under the sole crop rather than when inter-cropped with maize during both years (2001 and 2002) (Table 1.). At third application (55 DAS), endosulfan was significantly superior to A. indica oil and malathion in sole green gram as well as when green gram was inter-cropped with maize in the first year (2001) of experimentation. In the next year (2002), the efficacy of endosulfan was more pronounced in the sole crop rather than when green gram was inter-cropped with maize. During the first season (2001) A. indica oil happened to be more effective than malathion against whiteflies, whereas, in the subsequent year (2002) A. indica oil and malathion had a similar effect irrespective of cropping pattern. Foliar application with cypermethrin, deltamethrin and dimethoate 50 days after sowing of green gram proved quite effective in reducing the incidence of Bemisia tabaci and the virus (1). The maximum effectiveness was recorded by Borah et al (1996) for dimethoate $(0.03 \%)$ at 15 and 30 days after germination, followed by dimethoate $(0.03 \%)$ at 15 days after germination + malathion $(0.05 \%)$ at 30 days after germination. The use of cotton as a trap crop, sown one month ahead between the green gram rows, with a single spray of dimethoate $(0.03 \%)$ at 15 days after germination of green gram, effectively controlled both Bemisia tabaci (11.83/10 plants) and yellow mosaic virus (7.81\%).

\section{Efficacy of management schedules (55 DAS) against pod borers}

\section{(i) Lycaenid pod borer}

Endosulfan was most effective against the borer infesting green gram either as sole crop or when inter-cropped with maize recording the lowest pod damage in both the years (2001 and 2002) of study. The efficacy of A. indica oil was intermediate, but was more pronounced when green gram was inter-cropped with maize. Malathion happened to be least effective against the borer in the both the years. The release of Chrysoperla carnea@25000/ha as a third application had an almost equal effect as that of malathion but was better than control [Table 3., showing the comparative efficacy of different treatments on Lampides boeticus Linneaus infesting Vigna radiata (L.) Wilczek]. Comparing the efficacy of three synthetic pyrethroids: fenvalerate $(0.01 \%)$, cypermethrin $(0.0075 \%)$ for the control of Euchrysops cnejus on green gram (Vigna radiata) and cowpea (Vigna unguiculata) with that of quinalphos $(0.05 \%)$ and endosulfan $(0.07 \%)$, it was observed that the performance of synthetic pyrethroids was superior to that of either quinalphos or endosulfan. The residue levels on pods were 
generally higher on cowpea than on green gram, but no residue of any compound except endosulfan (0.013 ppm in cowpea and $0.062 \mathrm{ppm}$ in green gram) was detected in the grain (6).

Table 3. Comparative efficacy of different treatments on Lampides boeticus Linnaeus infesting Vigna radiata (L.) Wilczek

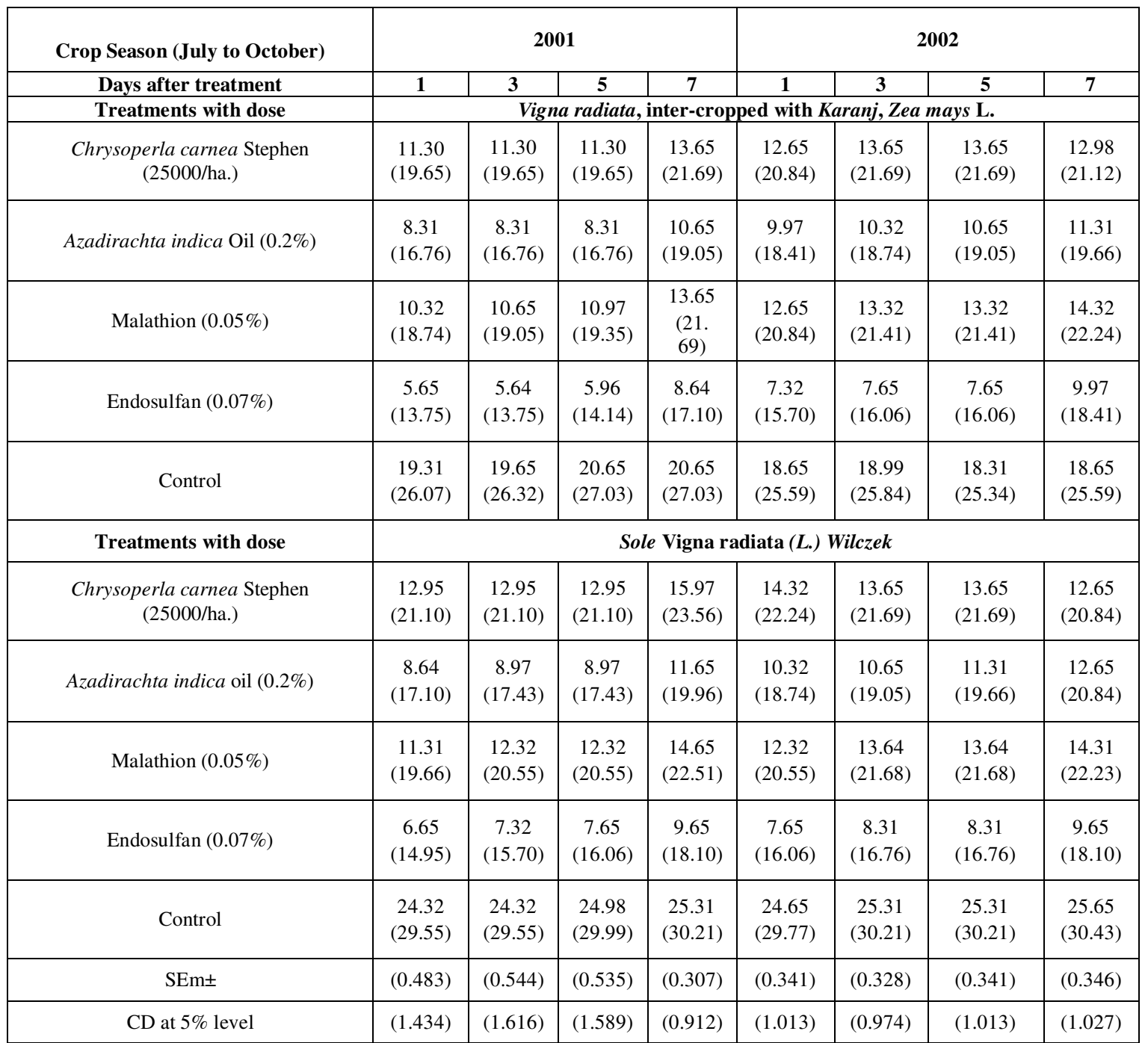

Data presented are per cent pod infestation. 2 Figures in parentheses are arc sine values.

\section{(ii) Spotted pod borer}

Endosulfan was most effective against spotted pod borer recording lowest pod infestation when green gram was inter-cropped with maize during both the years (2001 and 2002). A. indica oil was the next best treatment after endosulfan. During the two crop seasons, malathion as well as release of Chrysoperla carnea as third application were least effective against the spotted pod borer [Table 4., showing the comparative efficacy of different treatments on Maruca testulalis Geyer infesting Vigna radiate (L.) Wilczek].

Soil application of aldicarb at $1.0 \mathrm{~kg}$ a.i./ha combined with a spray of endosulfan $(0.07 \%)$ was more effective in reducing the incidence of yellow mosaic disease and 
damage by Maruca testulalis Geyar than a combination of endosulfan with soil applications of phorate or disulfoton both at $1.0 \mathrm{~kg}$ a.i./ha. However, disulfoton with endosulfan gave the highest increases in crop yield over the untreated variant 32.5 and 19.6 per cent for green gram (Pusa Baisaki) and black gram (T-9), respectively (7). In another field trial conducted under dry farming conditions in Tamil Nadu, India, during 1976-77 with green gram (Vigna radita) Var. Pusa Baisaki, Sundararaju and Rangrajan (1987) observed that a reduced incidence of yellow mosaic disease (transmitted by the aleyrodid Bemisia tabaci) and damage by pod borers (mainly the pyralid, Maruca testulalis) were obtained with a basal application of disulfoton at $1.0 \mathrm{~kg}$ a.i./ha and a spray of endosulfan $(0.07 \%)$, applied both at the time of flowering and 15 days later, in combination with fertilizer treatment at $25 \mathrm{~kg} \mathrm{~N}$ and $50 \mathrm{~kg} \mathrm{P}_{2} \mathrm{O}_{5} / \mathrm{ha}$. Yield of $V$. radiata increased by 48.7 per cent when both treatments were given simultaneously compared with 31.3 per cent with insecticides alone and 16.8 per cent with fertilizers alone.

Table 4. Comparative efficacies of different treatments on Maruca testulalis Geyer infesting Vigna radiata (L.) Wilczek

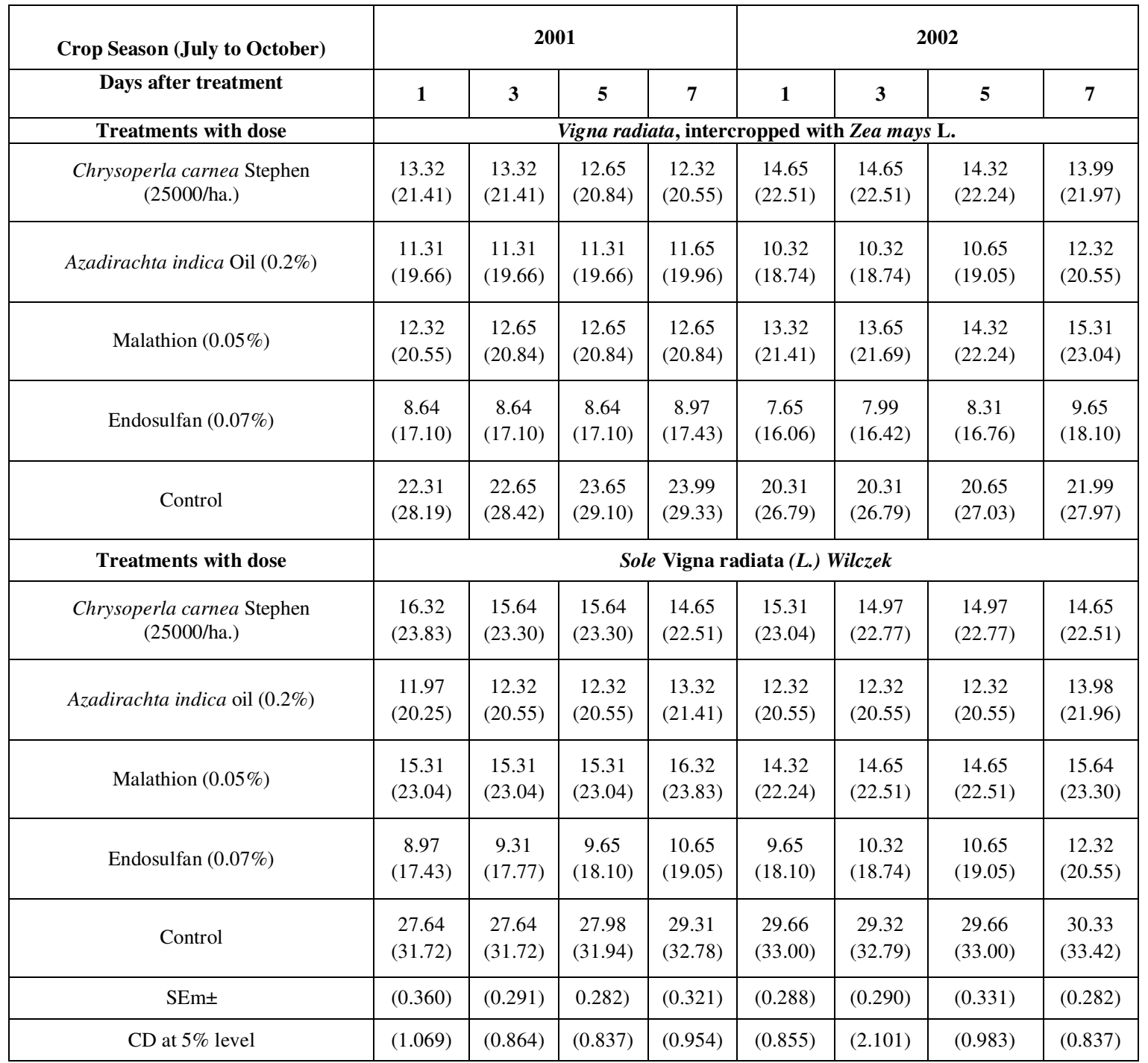

Data presented are per cent pod infestation. Figures in parentheses are arc sine values. 
Table 5. Comparative effect of different insect pest management schedules on the yield of Vigna radiata and Zea mays

\begin{tabular}{|c|c|c|c|c|c|c|c|c|c|}
\hline \multirow{3}{*}{$\begin{array}{l}\text { Schedule } \\
\text { No. }\end{array}$} & \multirow{2}{*}{\multicolumn{3}{|c|}{ Treatment schedule }} & \multicolumn{4}{|c|}{$\begin{array}{c}\text { Yield as kg./ } 12 \mathrm{~m}^{2} \text { (as q/ha) } \\
\text { in the inter crop }\end{array}$} & \multirow{2}{*}{\multicolumn{2}{|c|}{$\begin{array}{c}\text { Yield as kg./ } \\
12 \mathrm{~m}^{2} \text { (as } \\
\text { q/ha) } \\
\text { in sole crop } \\
\text { Greengram }\end{array}$}} \\
\hline & & & & \multicolumn{2}{|c|}{ Greengram } & \multicolumn{2}{|c|}{ Maize } & & \\
\hline & I (25 DAS) & II (40 DAS) & III (55 DAS) & 2001 & 2002 & 2001 & 2002 & 2001 & 2002 \\
\hline 2. & $\begin{array}{l}\text { C. carnea } \\
(25000 / \text { ha. })\end{array}$ & $\begin{array}{l}\text { C. carnea } \\
(25000 / \text { ha. })\end{array}$ & $\begin{array}{l}\text { C. carnea } \\
(25000 / \text { ha. })\end{array}$ & $\begin{array}{c}0.12 \\
(1.00)\end{array}$ & $\begin{array}{c}0.16 \\
(1.33)\end{array}$ & $\begin{array}{c}5.31 \\
(44.25)\end{array}$ & $\begin{array}{c}5.31 \\
(44.25)\end{array}$ & $\begin{array}{c}0.57 \\
(5.75)\end{array}$ & $\begin{array}{c}0.65 \\
(5.42)\end{array}$ \\
\hline 3. & $\begin{array}{l}\text { A. indica Oil } \\
\quad(0.2 \%)\end{array}$ & $\begin{array}{l}\text { A. indica Oil } \\
(0.2 \%)\end{array}$ & $\begin{array}{l}\text { A. indica Oil } \\
(0.2 \%)\end{array}$ & $\begin{array}{c}0.25 \\
(2.08)\end{array}$ & $\begin{array}{c}0.23 \\
(1.92)\end{array}$ & $\begin{array}{c}6.54 \\
(54.50)\end{array}$ & $\begin{array}{c}6.94 \\
(57.83)\end{array}$ & $\begin{array}{c}0.76 \\
(6.33)\end{array}$ & $\begin{array}{c}0.83 \\
(6.92)\end{array}$ \\
\hline 5. & $\begin{array}{c}\text { C. carnea } \\
(25000 / \text { ha. })\end{array}$ & $\begin{array}{l}\text { A. indicaOil } \\
(0.2 \%)\end{array}$ & $\begin{array}{l}\text { Endosulfan } \\
(0.07 \%)\end{array}$ & $\begin{array}{c}0.34 \\
(2.83)\end{array}$ & $\begin{array}{c}0.30 \\
(2.50)\end{array}$ & $\begin{array}{c}6.96 \\
(58.00)\end{array}$ & $\begin{array}{c}7.61 \\
(63.42)\end{array}$ & $\begin{array}{c}0.89 \\
(7.42)\end{array}$ & $\begin{array}{c}0.99 \\
(8.25)\end{array}$ \\
\hline 6. & Control & Control & Control & $\begin{array}{c}0.09 \\
(0.75)\end{array}$ & $\begin{array}{c}0.10 \\
(0.83)\end{array}$ & $\begin{array}{c}4.02 \\
(33.50)\end{array}$ & $\begin{array}{c}4.10 \\
(34.16)\end{array}$ & $\begin{array}{c}0.42 \\
(3.50)\end{array}$ & $\begin{array}{c}0.51 \\
(4.25)\end{array}$ \\
\hline & \multirow{2}{*}{\multicolumn{3}{|c|}{$\begin{array}{c}\text { S. Em. } \pm \\
\text { CD at } 5 \% \text { level }\end{array}$}} & 0.002 & 0.007 & 0.03 & 0.006 & 0.010 & 0.017 \\
\hline & & & & 0.007 & 0.024 & 0.09 & 0.021 & 0.032 & 0.054 \\
\hline
\end{tabular}

DAS=Days after sowing

\section{Effect of management schedules on grain yield}

During both the seasons (2001 and 2002) the maximum yield of maize and green gram in the inter-cropped pattern and that of green gram in sole crop was recorded for the management schedule comprising release of Chrysoperla carnea 25 DAS, A. indica oil 40 DAS and endosulfan 55 DAS; whereas, the management schedule comprising Chrysoperla carnea 25 DAS, A. indica oil 40 DAS and malathion 55 DAS recorded the lowest yield in inter-cropping. The lowest yield of green gram was recorded under management schedule comprising three releases of Chrysoperla carnea at 25, 40 and 55 DAS. An overall observation showed that the net returns from inter-cropping were significantly higher than that of sole green gram, which is a clear case of cropping pattern advantage [Table 5., depicting the comparative effect of different insect pest management schedules on the yield of Vigna radiata $(\mathrm{L}$.$) and Zea mays L.].$

In an earlier study on nitrogen utilization efficiency, as affected by component populations in maize/ green gram inter-cropping, conducted at Los Banos, Philippines in 1988 dry season, maize (cv. IPB Var. 2) and green gram cv. Pag-asa (5) were grown in pure stands at their optimum plant populations of 50000 and 300000 plants/ha, respectively, or were intercropped in combinations of maize populations of 25000,50000 or $75000 /$ ha and green gram populations of 150000,300000 or 450000/ha. Maize grain yield was $3.82 \mathrm{t} / \mathrm{ha}$ in the pure stand and 2.16 to 2.55 t/ha when inter-cropped. Yield was not significantly affected by green gram plant density in the inter-crops, but was highest at a maize plant density of 50000/ha. Green gram seed yield was $1.57 \mathrm{t} / \mathrm{ha}$ in pure stand and 0.69 to $0.80 \mathrm{t}$ in inter-crops. In the inter-crops, green gram yield was highest at the lowest maize plant density and 300000 green gram plants/ha. Inter-cropping reduced nitrogen absorption by both crops. The proportional reduction in absorption efficiency of maize ranged from 0.28 to 0.37 and that of green grams from 0.50 to 0.57 . Increasing the maize population increased the $\mathrm{N}$ absorption efficiency of maize, but decreased the efficiency of green grams. The $\mathrm{N}$ absorption efficiency of all inter- 
crops was higher than that of the sole crops added together. Land equivalent ratio (LER) analysis showed that the LER was highest when both components of the inter-crop were at their optimum sole crop population, and that the yield advantage was primarily due to an increase in $\mathrm{N}$ absorption efficiency in the inter-crops (3).

\section{Effect of management schedules on rupee equivalent value}

Of the various management schedules compared for the rupee equivalent value obtained due to sole green gram as well as green gram inter-cropped with maize, the maximum rupee equivalent yield value during both years (2001 and 2002) of study was recorded for the management schedule comprising Chrysoperla carnea 25 DAS, A. indica oil 40 DAS and endosulfan 55 DAS (Rs. 39, 691 per hectare and Rs. 46, 291 per hectare). The next best treatment schedule comprised of three applications of $A$. indica oil at 25, 40 and 55 DAS (Table 6., showing the comparative rupee equivalent values for yield under different management schedules applied to Vigna radiata (L.) Wilczek, as sole crop and when intercropped with Zea mays L.].

Table 6. Comparative rupee equivalent values for yield under different management schedules applied to Vigna radiata $(\boldsymbol{L}$.) Wilczek as sole crop and when intercropped with Zea mays $\boldsymbol{L}$.

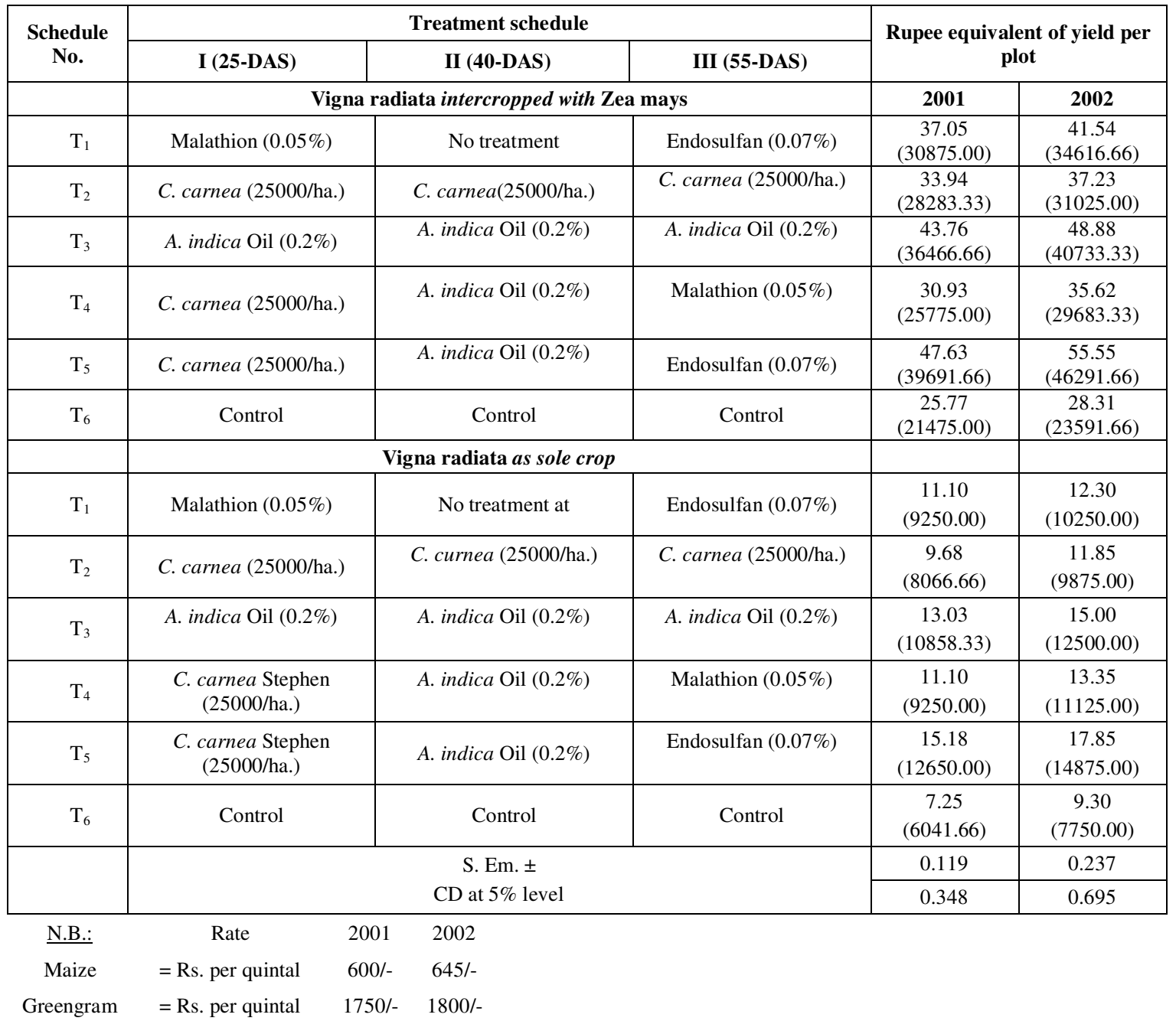

DAS $=$ Days after sowing 
Acknowledgements. The authors are thankful to the Dean, Rajasthan College of Agriculture and the Director of Research of Maharana Pratap University of Agriculture and Technology, for making available the necessary facilities to carry out the investigation.

\section{REFERENCES}

[1] Borah, R.K. (1995): Effect of synthetic pyrethroids and organo phosphorus insecticides on the incidence of whitely, Bemisia tabaci (Genn.) and yellow mosaic virus in green gram, Vigna radiata (L.) Wilczek. - Indian Journal of Virology 11: 75-76.

[2] Borah, R.K., Nath, P.D. and Deka, N. (1996): Effect of insecticides and trap crop on the incidence of whitefly, Bemisia tabaci (Genn.) and yellow mosaic virus in green gram, Vigna radiata (L.) Wilczek. - Indian Journal of Virology 12: 75-77.

[3] Chowdhury, M.K. and Rosario, E.L. (1993): Nitrogen utilization efficiency as affected by component populations in maize-mung bean inter-cropping. - Tropical Agriculture. 70: 199-204.

[4] Gopalan, C., Rama Shastri, B.V. and Balasubramanian, S.C. (1977): Nutritive value of Indian foods (ed.) Saini. - ICAR Pub. New Delhi.

[5] Henderson, C.F. and Tilton, E.W. (1955): Test with against the brown wheat mite. Journal of Economic Entomology 48: 157-161.

[6] Srivastava, P.K., Gajbhiye, V.T., Jain, H.K. and Agnihotri, N.P. (1984): Efficacy of synthetic pyrethroids against the pod borer, Euchrysops cnejus (Fabricius) and their residues in green gram, Vigna radiata (L.) Wilezek and Cowpea, Vigna unguiculata (L.) Walp. - Journal of Entomological Research 8: 36-41.

[7] Sundararaju, D. and Rangarajan, A.V. (1987): Insecticidal control of pests of green gram and black gram. - Pesticides 21: 18-9.

[8] Vavilov, N.I. (1926): Studies on the origin of cultivated plants. - Bulletin of Applied Botany and Plant Breeding 16(2) 